\title{
EFFECT OF DIRECT LIQUID WATER INJECTION AND INTERDIGITATED FLOW FIELD ON THE PERFORMANCE OF PROTON EXCHANGE MEMBRANE FUEL CELLS
}

\author{
By
}

\author{
David L. Wood, III, Jung S. Yi, and Trung V. Nguyen* \\ Department of Chemical and Petroleum Engineering \\ University of Kansas \\ Lawrence, Kansas 66045
}

\author{
Submitted as a Research Paper to \\ ELECTROCHIMICA ACTA JOURNAL \\ Dr. Elton J. Cairns, North American Regional Editor \\ Environmental Energy Technologies Division \\ Lawrence Berkeley National Laboratory \\ MS 70-108B \\ One Cyclotron Road \\ Berkeley, California 94720
}

December 2, 1997

Key Words: Proton Exchange Membrane fuel cells, humidification, gas distribution, direct liquid water injection, interdigitated flow fields.

* Corresponding author

Tel: 785-864-3938, Fax: 785-864-4967, E-mail: cptvn@kuhub.cc.ukans.edu 


\begin{abstract}
Proper water management is vital to ensuring successful performance of proton exchange membrane fuel cells. The effectiveness of the direct liquid water injection scheme and the interdigitated flow field design towards providing adequate gas humidification to maintain membrane optimal hydration and alleviating the mass transport limitations of the reactants and electrode flooding is investigated. It is found that the direct liquid water injection used in conjunction with the interdigitated flow fields as a humidification technique is an extremely effective method of water management. The forced flow-through-the-electrode characteristic of the interdigitated flow field 1) provides higher transport rates of reactant and products to and from the inner catalyst layers, 2) increases the hydration state and conductivity of the membrane by bringing its anode/membrane interface in direct contact with liquid water, and 3) increases the cell tolerance limits for excess injected liquid water, which could be used to provide simultaneous evaporative cooling. Experimental results show substantial improvements in performance as a result of these improvements.
\end{abstract}




\section{INTRODUCTION}

Proton Exchange Membrane (PEM) fuel cells are becoming more popular as direct electrical energy conversion devices because of their high efficiency and simplicity in design and operation made possible by the use of a proton conducting membrane as the electrolyte. Some attractive characteristics of the PEM fuel cells include $\mathrm{CO}_{2}$ tolerance, self-starting at low temperatures, and low-cost construction materials. The attractiveness of this fuel cell system has increased significantly with improvements in many areas. However, the system is still not fully optimized in terms of performance to be competitive with the principal competitor, the combustion engine.

Improvements in the performance area can be identified by evaluating the polarization curve of a fuel cell. See Figure 1. This curve can be separated into three regions. The sharp voltage drop of the first region associated with the activation resistance is attributed to the type of catalyst and the catalyst surface area that is in contact with the electrolyte and the electrical network in the electrode and is accessible to the reacting gases. Lowering this resistance will raise the whole polarization curve. The gradual drop in voltage of the second region, known as the ohmic voltage loss, is attributed to the electronic, ionic and contact resistance of the components within the electrical network of the fuel cell such as the electrodes, membrane and current collecting components. Lowering this resistance will raise the polarization curve and reduce the slope of the curve resulting in higher power densities at higher energy efficiencies.

The sharp voltage drop of the third region, known as the voltage loss associated with the mass transport resistance, is attributed to concentration polarization, which occurs as a result of the depletion of the reactant at the reaction interface as its transport to the reaction sites fails to keep up with the reaction rate. This phenomenon is especially severe at the cathode of the fuel cell where oxygen is the reactant because of the presence of liquid water within the porous structure of the electrode and on the catalyst/membrane surface. This liquid water, which is the 
product of the cathodic reaction and proton transport from the anode, acts as an additional barrier to the transport of oxygen to the reaction sites. Minimizing this resistance will allow the ohmic region to be extended resulting in much higher power densities.

Voltage loss in the first region can be reduced by using catalysts with lower activation resistance or increasing the catalyst surface available for reaction per unit volume of electrode. Currently, platinum is the best catalyst available. Efforts of sputtering the catalyst onto the surface of the electrode that is later hot pressed onto the membrane and mixing the catalystsubstrate with the membrane ionomer into an ink and applying it directly onto the membrane have resulted in significant improvements in the fuel cell performance and major reduction in the catalyst loading, from as high as $5 \mathrm{mg} \mathrm{Pt} / \mathrm{cm}^{2}$ to $0.2 \mathrm{mg} \mathrm{Pt} / \mathrm{cm}^{2},{ }^{1-6}$. Note that the voltage loss caused by gas crossover can be minimized by using a thicker membrane and keeping the membrane well hydrated. However, reduction in voltage loss by gas crossover by using a thicker membrane must be considered against the additional ohmic voltage loss of a thicker membrane.

Voltage loss in the second region has been successfully reduced by humidifying the reactant gases, especially the anode gas, and employing thinner membranes and membranes with lower ionic and water transport resistances. ${ }^{7-9}$ Figure 2 shows some of various humidification schemes that could be used to humidify the anode gas (and the cathode gas if air is used). ${ }^{10}$ Note that these examples are in no way exhaustive. The conventional design involves supplying water-saturated reactant gas streams, which are typically achieved by passing the gas streams through a column of water. In this case, the amount of water that can be brought into the cell will therefore depend on the humidification temperature. Low temperatures result in low water partial pressures, while high temperatures result in low reactant partial pressures. In contrast, the vapor injection design calls for complex electrode designs, possibly consisting of porous backing plates for continuous water addition along the flow 
channels. Components for this scheme would be more expensive to construct and difficult to incorporate into a stack of cells. ${ }^{11}$ The recirculation design would also be satisfactory, however, this method requires an external piece of equipment to recirculate the gas. Of these four examples, the direct liquid water injection approach appears most attractive because of its simplicity and efficiency. This approach allows more water to be introduced into the reaction compartment to keep the membrane hydrated than that possible by just saturating the incoming gas streams. That is, as water in the form of vapor is lost from the anode gas by the net transport of water from the anode to the cathode (electro-osmosis minus back diffusion), more water can be generated by the evaporation of liquid water. Furthermore, this liquid water evaporation provides simultaneous cooling to the cell and can be used as a very effective thermal management system. However, application of the direct liquid water injection in PEM fuel cells had been very difficult because excessive amounts lead to electrode flooding. The direct liquid water injection scheme was first tried in 1989 but was quickly dropped because of the problems just mentioned. ${ }^{12}$ Recently, with the development of the interdigitated flow field (to be described further below), it was tried again and found to work very well.

The last voltage loss region associated with mass transport limitation has not been fully addressed. So far it has been solved indirectly by raising the gas pressure (increasing the local concentrations) and partially by raising the gas stoichiometric flow rates which result in lower energy efficiencies. Recently, a new flow field design called the interdigitated flow field was developed to address this problem directly. ${ }^{13,14}$ See Figures 3 and 4 . By forcing the gas to flow into the electrodes in order to exit as compared to flowing over the surface of the electrodes in a "conventional" flow field, the transport of the reactant and product gases to and from the catalyst layers are converted from a diffusion mechanism to a forced convection mechanism. As a result, the diffusion (stagnant) layer is reduced from the whole electrode thickness consisting of the catalyst layer and macro-porous backing layer to a much thinner combined catalyst and 
boundary layer. Furthermore, the shear force of this gas flow helps to remove a large amount of the liquid water that is entrapped in the inner layers of the electrode, thereby significantly reducing the electrode flooding problem. ${ }^{14}$ The forced-flow-through characteristic created by the interdigitated flow field also enables the cell to handle two-phase (liquid water and reactant gas) flow allowing the direct liquid water injection scheme to be used effectively. By introducing liquid water directly into the anode and allowing it to contact the anode membrane interface provides an additional benefit of possibly higher membrane hydration and therefore higher conductivity. It has been found that membranes immersed in liquid water have higher water contents than those in contact with water vapor. ${ }^{15}$

Finally, it is important to point out that the effectiveness of the direct liquid water injection scheme has been theoretically evaluated and proven by mathematical models. ${ }^{10,16}$ This paper reports experimental results on the effectiveness of the direct liquid water injection scheme and the interdigitated flow field design in improving the performance of proton exchange membrane fuel cells.

\section{EXPERIMENTAL}

The fuel cell used in this study consists of two copper bus plates to collect the current, machined graphite flow fields for distribution of reactant gases, and a pre-gasketed membrane and electrode assembly (MEA) provided by W.L. Gore \& Associates, Inc. The MEA's used had either a $20 \mu \mathrm{m}$ - or $40 \mu \mathrm{m}$-thick GORE-SELECT ${ }^{\mathrm{TM}}$ membrane with an equivalent weight of 950 and a catalyst loading of $0.3 \mathrm{mg} \mathrm{Pt} / \mathrm{cm}^{2} /$ electrode. The cell had an active surface area of 100 $\mathrm{cm}^{2}$ per electrode. The macro-porous diffusion layers placed on top of the catalyst layers were made of waterproof, carbon fiber cloths. Liquid water was injected by two metering pumps into two heated stainless steel coils, where it was preheated to the cell operating temperatures, and then directly into the gas streams. Unless otherwise stated, cell pressures reported are outlet pressures. Pressure drops across the cell were measured with water manometers, and gas flow 
was controlled by mass flow controllers.

Anode and cathode liquid water injection rates for the base case of each set of operating conditions were chosen as the minimum settings on the water metering pumps, corresponding to $0.53 \mathrm{~g} \mathrm{H}_{2} \mathrm{O} / \mathrm{min}$ for the cathode pump and $0.50 \mathrm{~g} \mathrm{H}_{2} \mathrm{O} / \mathrm{min}$ for the anode pump. Stoichiometric equivalent flow rates of $2.5 \mathrm{~A} / \mathrm{cm}^{2}$ and $3.0 \mathrm{~A} / \mathrm{cm}^{2}$ were chosen for the hydrogen and oxygen flow rates, respectively, translating into $0.36 \mathrm{~mol} \mathrm{H}_{2} \mathrm{O} / \mathrm{mol} \mathrm{H}_{2}, 0.64 \mathrm{~mol} \mathrm{H}_{2} \mathrm{O} / \mathrm{mol} \mathrm{O}_{2}$, and $0.20 \mathrm{~mol} \mathrm{H}_{2} \mathrm{O} / \mathrm{mol}$ Air.

Using the minimum amount of humidification allowed by the equipment as a reference point, variations in performance were evaluated by increasing the anode or cathode water flow rate until a maximum level of improvement over the base case was attained. It was also desired to examine the effect of flowing each gas stream into the cell with no humidification while holding the other stream at the base-case water injection level. Performing these trials at various conditions would verify whether the anode or cathode is more sensitive to humidification and to what degree. To illustrate the effectiveness of the direct liquid water injection scheme when used in conjunction with the interdigitated flow fields, the direct liquid water injection scheme was also applied to a "conventional" flow field design in which the reactant gases were flown along parallel channels over the outer surface of the electrodes. The same operating conditions were used in both flow field designs. Examining these effects comprise the major objective of this work. Other effects of interest include those of membrane thickness and air operation versus oxygen operation.

\section{RESULTS AND DISCUSSION}

Results presented in this paper are intended to be an expanded, more detailed analysis of results first published by Nguyen ${ }^{14}$ which confirmed the effectiveness of the interdigitated flow field design at ambient operating conditions with GlobeTech, Inc. MEA's. All data shown here were obtained using MEA's from W.L. Gore and Associates, Inc. Except for the results shown in Figures 10 and 11, the MEA with a $40 \mu \mathrm{m}$ membrane thickness was used. The MEA with a 
$20 \mu \mathrm{m}$ thickness was used for the data taken and shown in Figures 10 and 11 . Results where pure oxygen was used as the cathode reactant will be presented first followed by those where air was used as the cathode reactant.

Liquid Water Injection with Oxygen as the Cathode Gas:

Upon examining Figures 5 and 6, the most striking feature is the marked performance improvement achieved simply by providing optimal humidification to the anode. Drastic improvements were observed at $80^{\circ} \mathrm{C}$ and 1 atm abs using either type of flow field design as the cathode water flow rate was held constant and the anode water flow rate was increased. As would be expected, the worst performance was seen for both designs when the hydrogen stream was not humidified. For every anode water flow rate, the interdigitated design yielded superior performance over the conventional design, and the optimized maximum power densities were about $0.57 \mathrm{~W} / \mathrm{cm}^{2}$ and $0.42 \mathrm{~W} / \mathrm{cm}^{2}$, respectively (see Figure 6). It is also interesting to observe that the interdigitated flow fields could handle more liquid water at the anode than the conventional flow fields. Comparing the curves in Figure 5 where the anode water flow rates were increased from $0.36 \mathrm{~mol} \mathrm{H}_{2} \mathrm{O} / \mathrm{mol} \mathrm{H}_{2}$ to $2.0 \mathrm{~mol} \mathrm{H}_{2} \mathrm{O} / \mathrm{mol} \mathrm{H}_{2}$ illustrates this point. Performance for cells using the interdigitated flow fields continued to increase as the amount of injected liquid water increased while that for cells using the conventional ones dropped significantly as the injected liquid water was increased from 1.2 to $2.0 \mathrm{~mol} \mathrm{H}_{2} \mathrm{O} / \mathrm{mol} \mathrm{H}_{2}$. Note that at $80^{\circ} \mathrm{C}$ and $1 \mathrm{~atm}$ abs, $100 \%$ water saturation would correspond to $0.90 \mathrm{~mol} \mathrm{H}_{2} \mathrm{O} / \mathrm{mol}$ $\mathrm{H}_{2}$.

This finding is explained by the fact that the interdigitated design provides more uniform reactant supply and at a higher rate to the reactive interface than the conventional design. ${ }^{14}$ In addition, at the anode side, having liquid water that is carried by the gas stream in direct contact with the electrode and membrane interface provides more water for electro-osmosis without flooding the anode catalyst layer, higher membrane water content, and, consequently, higher 
membrane conductivity. ${ }^{15}$ At the cathode side, the dead-ended flow channels cause the electrode layer to be continuously purged of liquid water, a benefit not physically possible with conventional flow channels. These points are further solidified by the fact that the region of mass transfer limitations was reached at much lower current densities with conventional flow fields, indicated by the steeper slopes at the end of the voltage curves in Figure 5 and the peaks of the power density curves in Figure 6 . When the interdigitated design was used, only the trial where the hydrogen stream was not humidified was the maximum power density reached. In contrast, all trials but one reached the mass transfer region when the conventional design was used. A maximum power density improvement of $\sim 0.21 \mathrm{~W} / \mathrm{cm}^{2}$ to $\sim 0.57 \mathrm{~W} / \mathrm{cm}^{2}$ (or about $170 \%$ ) was obtained by changing from conventional flow fields and no anode water injection to interdigitated flow fields and optimized anode water injection. The maximum power density enhancement gained exclusively from anode water injection using the interdigitated flow fields went from $\sim 0.27 \mathrm{~W} / \mathrm{cm}^{2}$ with no anode water to $\sim 0.57 \mathrm{~W} / \mathrm{cm}^{2}$ with $2.0 \mathrm{~mol} \mathrm{H} \mathrm{H}_{2} \mathrm{O} / \mathrm{mol} \mathrm{H}_{2}$, a remarkable improvement of about $110 \%$.

One could have suspected that the pressure drop across these flow field shoulders (area of flow field in electrical contact with the electrode) to be high, and if that was the case, the increase in performance could be attributed to the higher pressure. On the contrary, we found the pressure drop to be minimal. For the high stoichiometric flow rates used here, the pressure drop across a $1 \mathrm{~mm}$ shoulder were measured at approximately $0.067 \mathrm{~atm}$ for the hydrogen side and 0.08 atm for the oxygen side, respectively. That is, for a small $7-8 \%$ increase in pressure we get from $30 \%$ to over $100 \%$ increase in performance. We attribute this small pressure drop to the highly porous structure of the carbon fiber cloth used and the short shoulder length over which the gas must travel. Of course, when air is used instead of oxygen the pressure drop will be 5 times higher, which is still a small penalty.

Figures 7 and 8 show results for the cases holding the anode water flow rate constant and varying the cathode water flow rate. Similar performance improvement was obtained, but 
the maximum attainable power density using either flow field design was lower upon optimizing the cathode water flow rate than that under optimized anode water flow rates (Figure 8 vs. Figure 6). This observation shows that humidification optimization is more important for the anode gas stream but still cannot be ignored for the cathode stream. Again the interdigitated flow fields could handle more cathode water than the conventional flow fields as indicated by Figure 8. When the cathode water flow rate was increased from $0.64 \mathrm{~mol} \mathrm{H}_{2} \mathrm{O} / \mathrm{mol} \mathrm{O}_{2}$ to 1.3 mol $\mathrm{H}_{2} \mathrm{O} / \mathrm{mol} \mathrm{O}_{2}$, performance increased moderately with the interdigitated flow fields and decreased significantly with the conventional flow fields. This trend indicates that the cathode is more sensitive to flooding with liquid injection especially when conventional flow fields are used, which agrees well with intuition since water accumulates by reaction and electro-osmosis at the cathode interface. Finally, similarly to the anode water injection study, the mass transfer region of operation was reached at a much lower current density with the conventional design than with the interdigitated design (see Figures 6 and 8).

Shown in Figures 9 and 10 are the results of the anode water injection study performed at $60^{\circ} \mathrm{C}$ and 1 atm abs using a MEA which has a membrane thickness of $20 \mu \mathrm{m}$. Simply reducing the membrane thickness had multiple effects on the cell performance. However, the general trends of improved performance of the interdigitated design over the conventional design and increased performance with increasing anode water flow rate remain steadfastly in tact. Even though the operating temperature was reduced by $20^{\circ} \mathrm{C}$, the performance improved in every trial shown in Figure 9 over the corresponding trial shown in Figure 5, especially of those with no humidification and of the convention flow field design. Consequently, the improvement in performance from using conventional flow fields and no anode water (about $0.35 \mathrm{~W} / \mathrm{cm}^{2}$ ) to using interdigitated flow fields and optimized anode water injection (about 0.59 $\mathrm{W} / \mathrm{cm}^{2}$ ) decreased to about $68 \%$ as compared to $170 \%$ for the case with thicker membranes.

These observations are explained by the fact that a thinner membrane translates into 
shorter distance for back diffusion of water from the cathode to the anode to counter balance the water that is lost by electro-osmosis, thus reducing the need for adequate anode gas humidification. Consequently, cells with no humidification and conventional flow fields benefited greatly from this higher back diffusion rate, and even cells with direct liquid water injection and interdigitated flow fields showed some improvement from this benefit. All cells showed lower membrane ionic resistance (represented by the lower slopes in the ohmic region), which can be attributed in this case to both higher membrane hydration and its thinness. Finally, flooding of the cathode when conventional flow fields were used was also alleviated because of the higher back-diffusion rates of water to the anode, which is shown in Figure 10 in that none of the conventional flow field power density curves reached their peaks.

\section{Liquid Water Injection with Air Cathode:}

When air is used as the cathode reactant at the same pressure (i.e., $1 \mathrm{~atm}$ abs), a much higher mass flow rate must be used (about 4.76 times greater) to have the same mass of oxygen as a pure oxygen feed stream due to nitrogen presence. Furthermore, the partial pressure of oxygen is much lower, and the reactivity at the cathode is therefore reduced. The major effect on cell humidification when air is used instead of pure oxygen is that the higher mass flow rate dehydrates the MEA especially when the air stream is not humidified. With more water transported out of the cathode layer with the exit stream because of the higher mass flow rate, the direction of water diffusion across the membrane could change to the same direction as electro-osmosis (towards the cathode), which would further dehydrate the MEA ${ }^{10,16}$ Cathode humidification then becomes important both to promote back diffusion of water to the anode and to prevent dehydration at the cathode membrane interface. When dry air is used, membrane dehydration is expected to be most severe at region near the cell inlet, (the region of most importance because the electrode reaction rate could be at its highest level because of the high reactant concentration) for both flow field designs. Furthermore, membrane dehydration is expected to be even more severe for interdigitated flow field because dry air is forced to flow 
deeply into the electrode layers. This effect has been predicted earlier by mathematical models ${ }^{10,16}$ and confirmed experimentally here.

Figures 11 and 12 show air performance with various anode water injection levels for the case with temperature at $80^{\circ} \mathrm{C}$, pressure at 1 atm abs., a MEA with a $40 \mu \mathrm{m}$-thick membrane, and the cathode injected water level held constant at $0.20 \mathrm{~mol} \mathrm{H}_{2} \mathrm{O} / \mathrm{mol} \mathrm{O}_{2}$. It can be seen that the interdigitated flow fields still gave much better performance than the conventional flow fields for each anode humidification level. Figure 12 shows that the optimized maximum power density improved about $105 \%$ from $\sim 0.21 \mathrm{~W} / \mathrm{cm}^{2}$ (at $0.75 \mathrm{~mol} \mathrm{H} \mathrm{H}_{2} \mathrm{O} / \mathrm{mol} \mathrm{H}_{2}$ ) with the conventional design to $\sim 0.43 \mathrm{~W} / \mathrm{cm}^{2}$ (at $1.2 \mathrm{~mol} \mathrm{H} \mathrm{H}_{2} \mathrm{O} / \mathrm{mol} \mathrm{H}_{2}$ ) with the interdigitated design. An incredible improvement in maximum power density of about $760 \%$ was achieved in changing from conventional flow fields and no anode water (about $0.05 \mathrm{~W} / \mathrm{cm}^{2}$ ) to interdigitated flow fields and optimized anode water injection $\left(0.43 \mathrm{~W} / \mathrm{cm}^{2}\right)$. Solid performance improvement was also obtained for each design solely from optimizing the anode water flow rate. About $320 \%$ and $510 \%$ improvement, respectively, in maximum power density was obtained with the conventional and interdigitated flow fields from when no anode water was injected to when the anode water flow rate was optimized (see Figure 12). For every trial shown in Figure 11, the mass transfer region of operation was still reached with the conventional design well before it was reached with the interdigitated design.

The air performance shown in Figures 11 and 12 illustrates two main disparities from the oxygen performance shown in Figures 5 and 6. First, the combination of relatively dry air and dry hydrogen caused the membrane to dehydrate more severely, and the cell performance suffered greatly as a consequence of increased membrane resistivity as shown by the much poor performance of the no anode humidification cases in Figure 11. Once liquid water was added to the cell, the performance for both flow field designs increased significantly. The lower performance observed for the interdigitated flow field with air case versus that with pure oxygen case can be attributed to the lower oxygen partial pressure. Second, without the benefit of the 
flow-through characteristic of the interdigitated flow field, trials with conventional flow fields become mass transport much more quickly with air operation than with oxygen operation.

The effect of dry air operation, especially on cells with interdigitated flow fields, and the importance of cathode humidification when air is used are illustrated in Figures13 and 14. Note that the especially poor performance of the trial of no cathode water with the interdigitated flow field is even lower than that of the same trial with the conventional flow field. The results presented here confirmed the earlier predictions by mathematical models. ${ }^{10,16}$ Finally, note that the performance of the trials with the conventional flow fields continued to benefit from additional water added to the cell, while that of the trials with the interdigitated flow fields showed no further increase with additional water. This can be explained by the flow through characteristic of the interdigitated flow field which brings the humidified gas much closer to the electrode and membrane interface. Consequently, less water is needed to prevent membrane dehydration in the region near the inlet. Beyond this region sufficient amount of water is generated to keep the downstream region well humidified.

\section{CONCLUSIONS AND RECOMMENDATIONS}

The interdigitated design shows superior performance over the conventional design, due to its enhanced transport capabilities, for all cases whether air or pure oxygen is used as the cathode reactant. Using the interdigitated flow fields prolongs the point at which the mass transfer region of operation is reached, i.e., it is reached at higher current densities. The anode stream can handle a higher water flow rate with the interdigitated flow fields than with the conventional ones. Generally, anode humidification is more significant to achieving high cell performance than cathode humidification and results in greater performance improvement when optimized. Liquid water injection when used with the interdigitated flow field design is an extremely effective water management scheme. Using the higher liquid water tolerance levels

offered by the interdigitated flow fields, excess injected liquid water could be used as a heat removal scheme for PEM fuel cells. 
Effects of MEA type, membrane thickness, and catalyst layer thickness on liquid water injection must be systematically investigated before it can be completely determined if an optimum range of ratios of mass of liquid water to mass of reactant gas exists. Experiments quantifying the effects and potential benefits of liquid water injection on heat removal should be conducted to further illuminate the relationship between heat and water management.

\section{ACKNOWLEDGEMENTS}

The author would like to thank the University of Kansas, the State of Kansas, and the K*STAR NSF EPSCoR program for the financial support of this work. W. L. Gore and Associates, Inc. provided GORE-PRIMEA ${ }^{\mathrm{TM}}$ series 5000 membrane/electrode assemblies and macro-porous gas diffusion layers under confidential disclosure agreement. 


\section{Bibliography}

1. M.S. Wilson and S. Gottesfeld, J. Electrochem. Soc., 139, L28 (1992).

2. E.J. Taylor, E.B. Anderson, and N.R.K. Vilambi, J. Electrochem. Soc., 139, L45 (1992).

3. G. Sasikumar, M. Raja, and S. Parthasarathy, Electrochim. Acta, 40, 285 (1995).

4. M.S. Wilson, J.A. Valerio, and S. Gottesfeld, Electrochim. Acta, 40, 355 (1995).

5. T.R. Ralph, G.A. Hards, J.E. Keating, S.A. Campbell, D.P. Wilkinson, M. Davis, J. StPierre, and M.C. Johnson, J. Electrochem. Soc., 144, 3845 (1997).

6. I.D. Raistrick, U.S. Patent \#4826115 (1989).

7. J.A. Kolde, B. Bahar, M.S. Wilson, T.A. Zawodzinski, and S. Gottesfeld, in Proton Conducting Membrane Fuel Cell I, S. Gottesfeld, G. Halpert, and A. Landgrebe, Editors, PV 95-23, p. 193, The Electrochemical Society Proceedings Series, Pennington, NJ (1995).

8. J.S. Wainright, J.-T. Wang, D. Weng, R.F. Savinell and M. Litt, J. Electrochem. Soc., 142 , L121 (1995).

9. G.E. Wnek, J.N. Rider, J.M. Serpico, A.G. Einset, S.G. Ehrenberg, and L.A. Raboin, in Proton Conducting Membrane Fuel Cell I, S. Gottesfeld, G. Halpert, and A. Landgrebe, Editors, PV 95-23, p. 247, The Electrochemical Society Proceedings Series, Pennington, NJ (1995).

10. Trung V. Nguyen and Ralph E. White, J. Electrochem. Soc., 140, 2178 (1993).

11. P.J. Schutz, in Proceedings of the Symposium on Fuel Cells, R.E. White and A.J. Appleby, Editors, PV 89-14, p. 87, The Electrochemical Society Proceedings Series, Pennington, NJ (1989).

12. Trung Nguyen, James Hedstrom, and Nicholas Vanderborgh, in Proceedings of the Symposium on Fuel Cells, R.E. White and A.J. Appleby, Editors, PV 89-14, p. 39, The Electrochemical Society Proceedings Series, Pennington, NJ (1989).

13. Mahlon S. Wilson, Thomas E. Springer, John R. Davey, and Shimshon Gottesfeld, in Proton Conducting Membrane Fuel Cells I, S. Gottesfeld, G. Halpert, and A. Langrebe, Editors, PV 95-23, p. 115, The Electrochemical Society Proceedings Series, Pennington, NJ (1995).

14. Trung V. Nguyen, J. Electrochem. Soc., 143, L103 (1996).

15. T.E. Springer, T.A. Zawodzinski, and S. Gottesfeld, J. Electrochem. Soc., 138, 2334 (1991).

16. Jung S. Yi and Trung V. Nguyen, "An Along-the-Channel Model for Proton Exchange Membrane Fuel Cells," J. Electrochem. Soc., in press. 


\section{List of Figures}

1. Typical polarization curve of a PEM fuel cell.

2. Various anode gas humidification strategies for PEM fuel cells.

3. Gas transport inside a MEA using a conventional flow field design.

4. Gas transport inside a MEA using the interdigitated flow field design.

5. Performance comparison at $80^{\circ} \mathrm{C}$ between flow field designs using $\mathrm{O}_{2} / \mathrm{H}_{2}$ at various anode water injection levels.

6. Power density comparison at $80^{\circ} \mathrm{C}$ between flow field designs using $\mathrm{O}_{2} / \mathrm{H}_{2}$ at various anode water injection levels.

7. Performance comparison at $80^{\circ} \mathrm{C}$ between flow field designs using $\mathrm{O}_{2} / \mathrm{H}_{2}$ at various cathode water injection levels.

8. Power density comparison at $80^{\circ} \mathrm{C}$ between flow field designs using $\mathrm{O}_{2} / \mathrm{H}_{2}$ at various cathode water injection levels.

9. Performance comparison at $60^{\circ} \mathrm{C}$ between flow field designs using $\mathrm{O}_{2} / \mathrm{H}_{2}$ at various anode water injection levels for a thinner $(20 \mu \mathrm{m})$ membrane.

10. Power density comparison at $60^{\circ} \mathrm{C}$ between flow field designs using $\mathrm{O}_{2} / \mathrm{H}_{2}$ at various anode water injection levels for a thinner $(20 \mu \mathrm{m})$ membrane.

11. Performance comparison at $80^{\circ} \mathrm{C}$ between flow field designs using $\mathrm{Air} / \mathrm{H}_{2}$ at various anode water injection levels.

12. Power density comparison at $80^{\circ} \mathrm{C}$ between flow field designs using $\mathrm{Air} / \mathrm{H}_{2}$ at various anode water injection levels.

13. Performance comparison at $80^{\circ} \mathrm{C}$ between flow field designs using $\mathrm{Air} / \mathrm{H}_{2}$ at various cathode water injection levels.

14. Power density comparison at $80^{\circ} \mathrm{C}$ between flow field designs using $\mathrm{Air} / \mathrm{H}_{2}$ at various cathode water injection levels. 


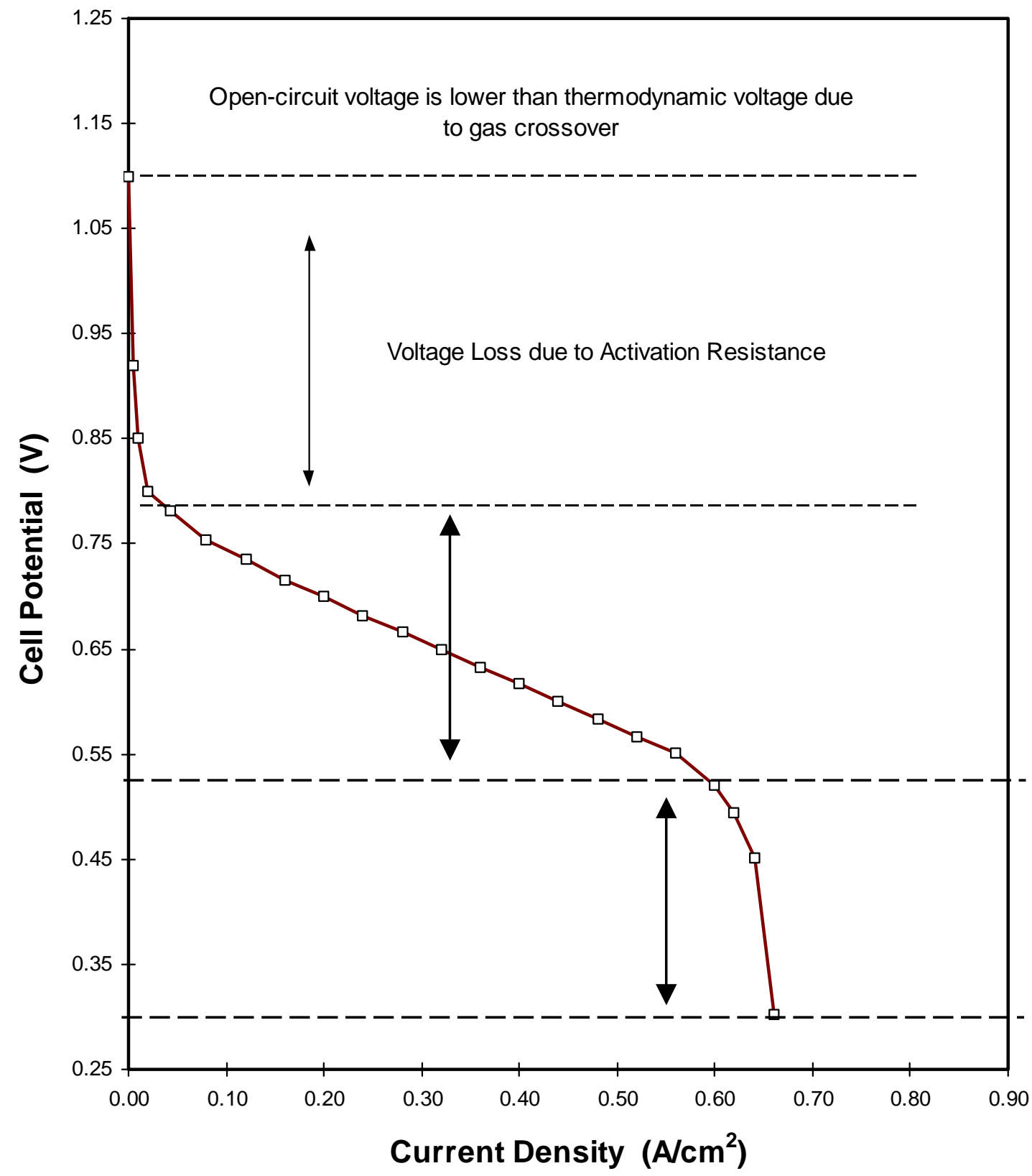

Figure 1. Typical polarization curve of a PEM fuel cell. 


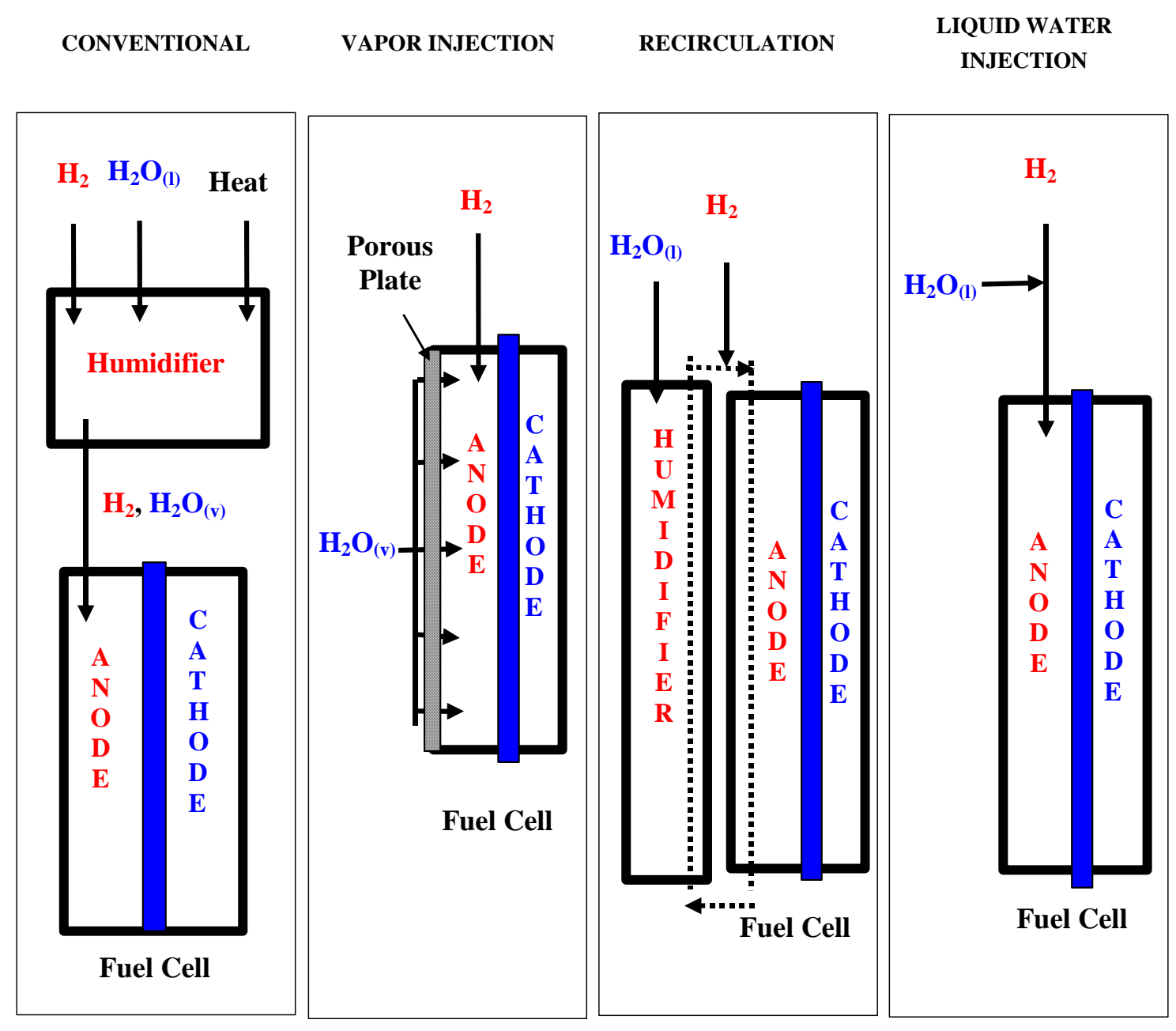

Figure 2. Various anode gas humidification strategies for PEM fuel cells. 


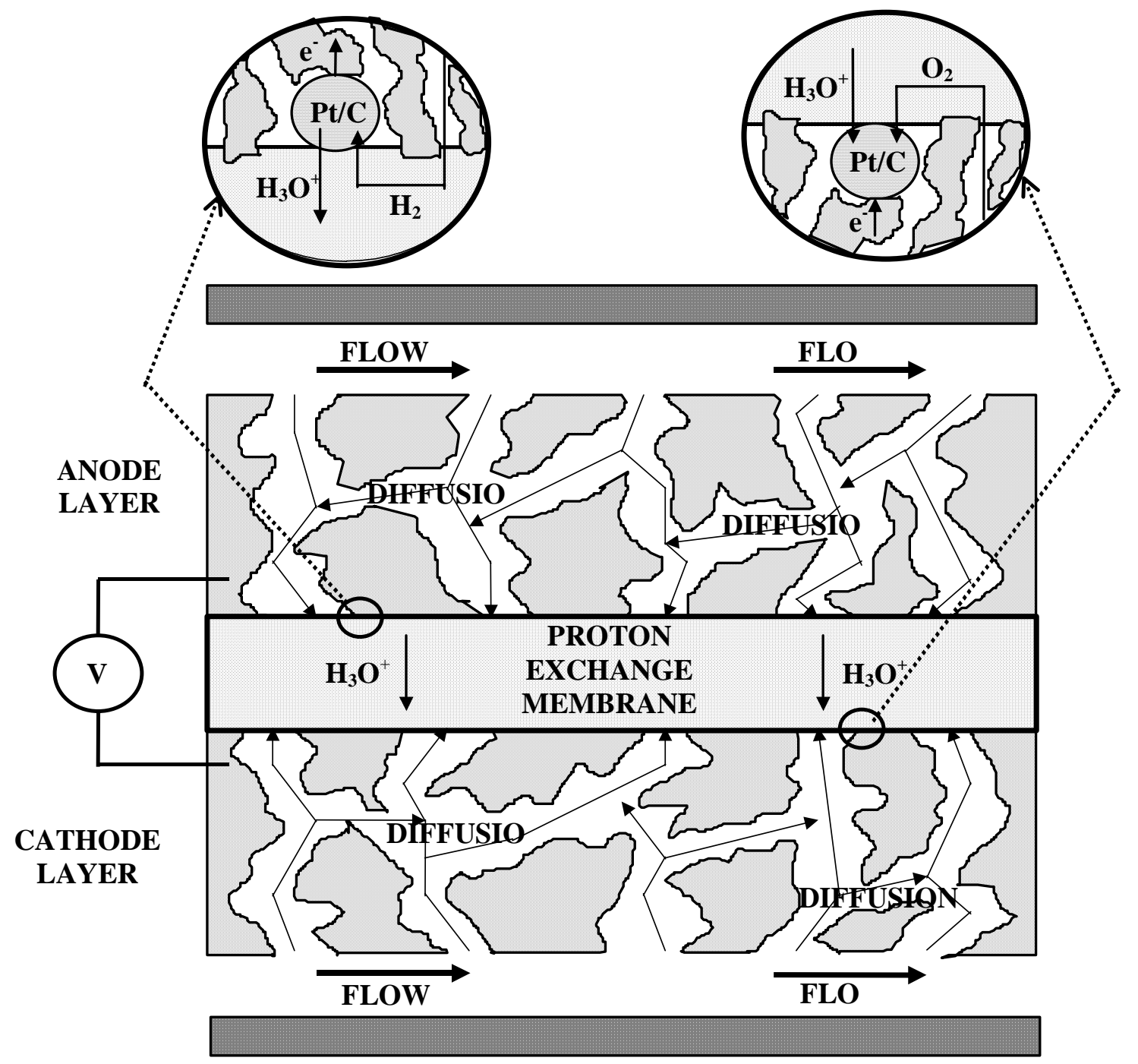

\section{Conventional Flow Field Design}

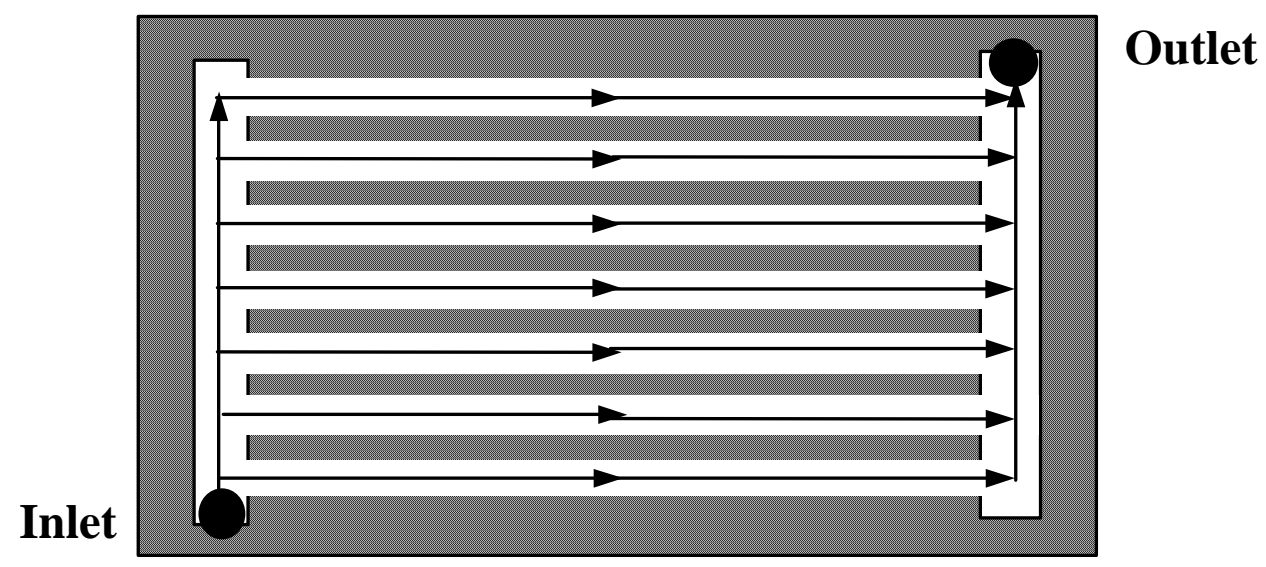

Figure 3. Gas transport inside a MEA using a conventional flow field design. 

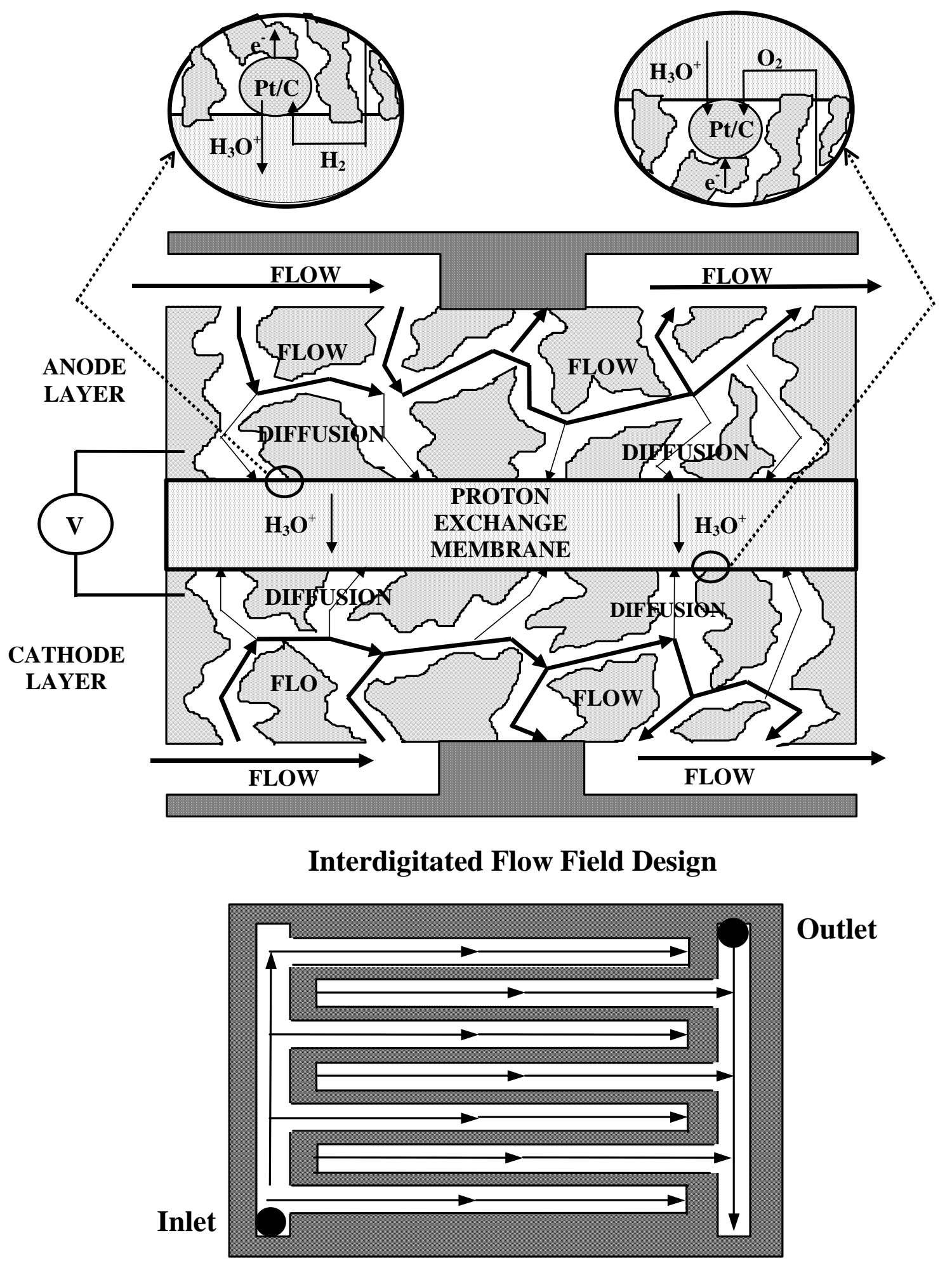

Figure 4. Gas transport inside a MEA using the interdigitated flow field design. 


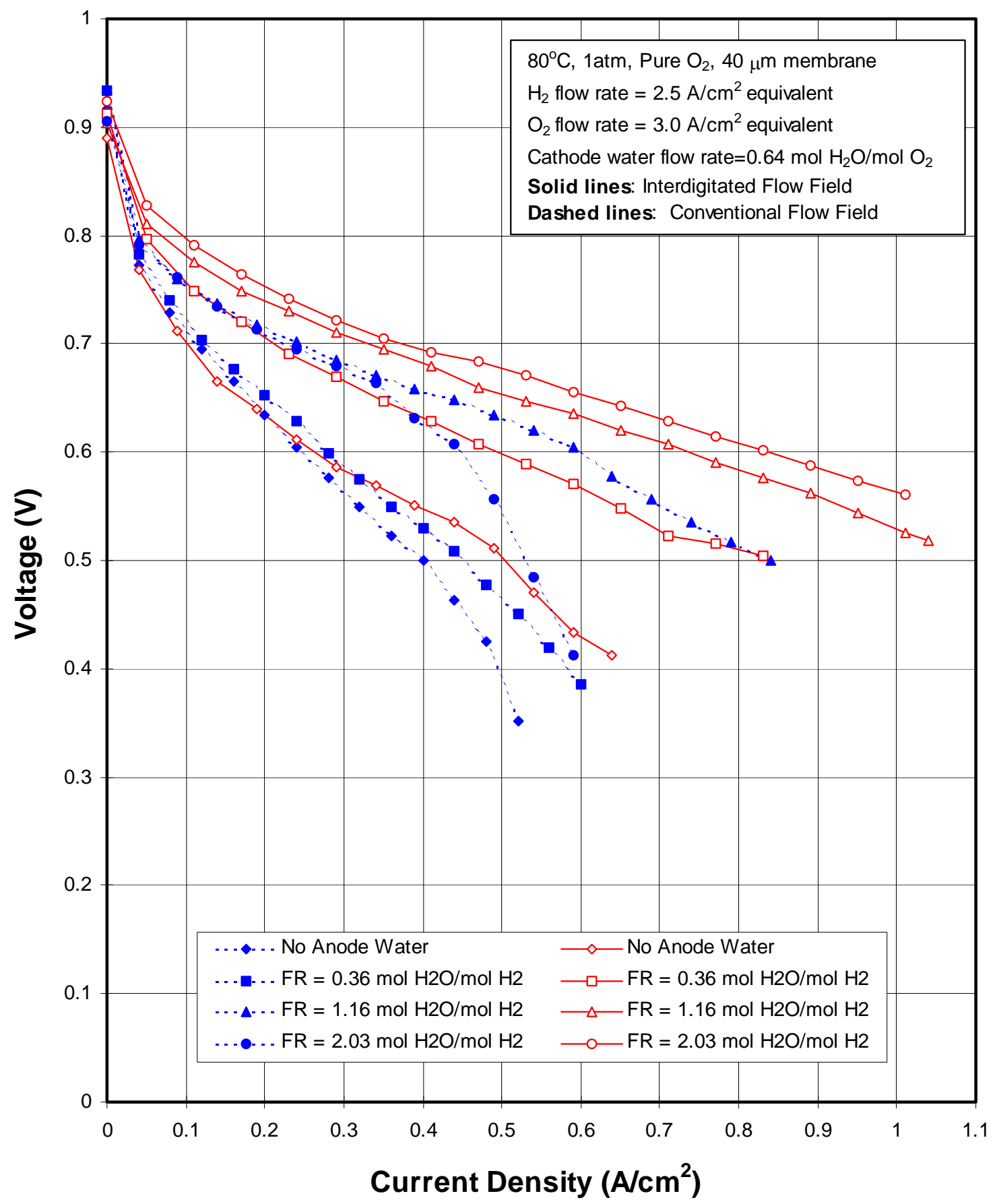

Figure 5. Performance comparison at $80^{\circ} \mathrm{C}$ between flow field designs using $\mathrm{O}_{2} / \mathrm{H}_{2}$ at various anode water injection levels. 


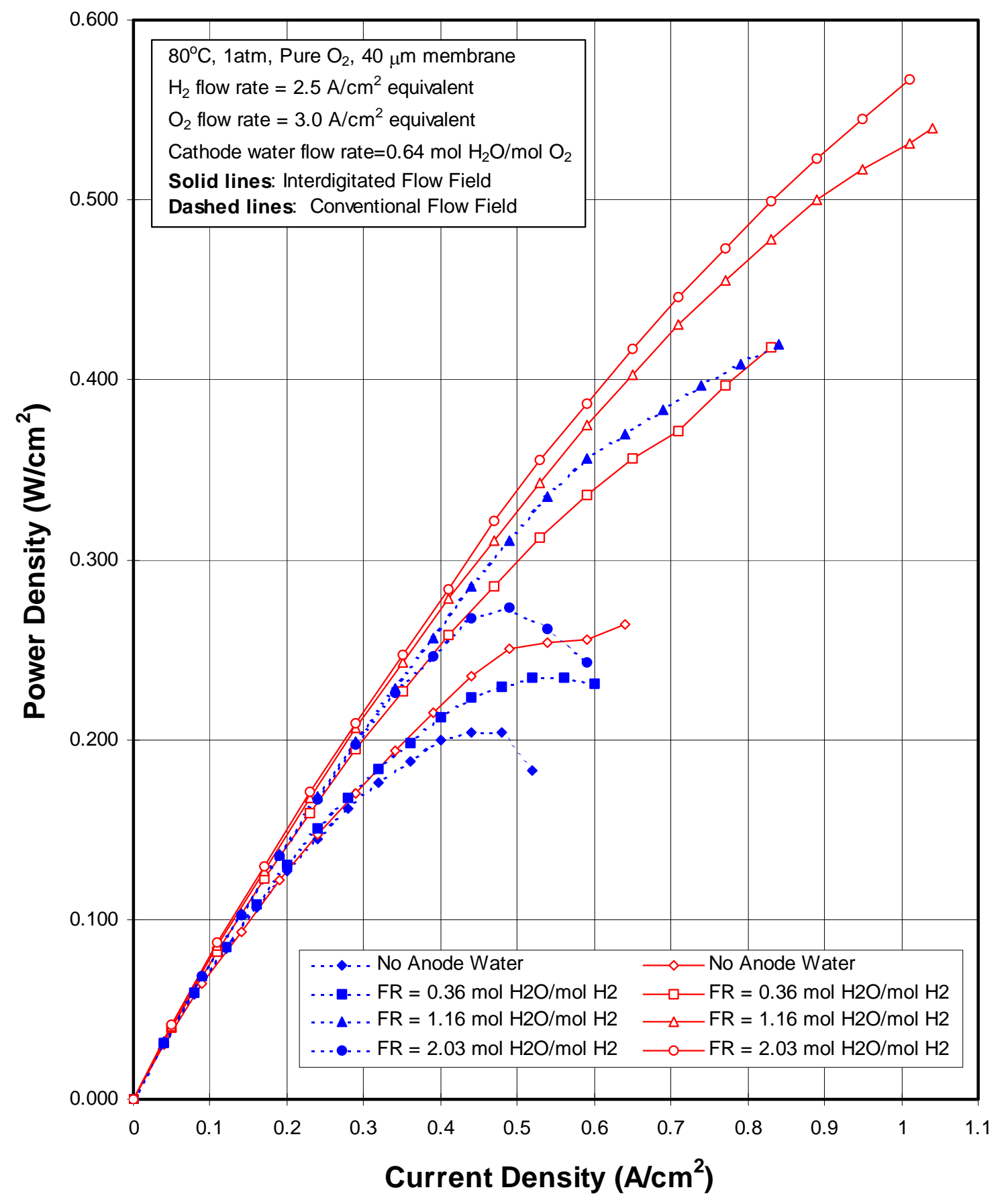

Figure 6. Power density comparison at $80^{\circ} \mathrm{C}$ between flow field designs using $\mathrm{O}_{2} / \mathrm{H}_{2}$ at various anode water injection levels. 


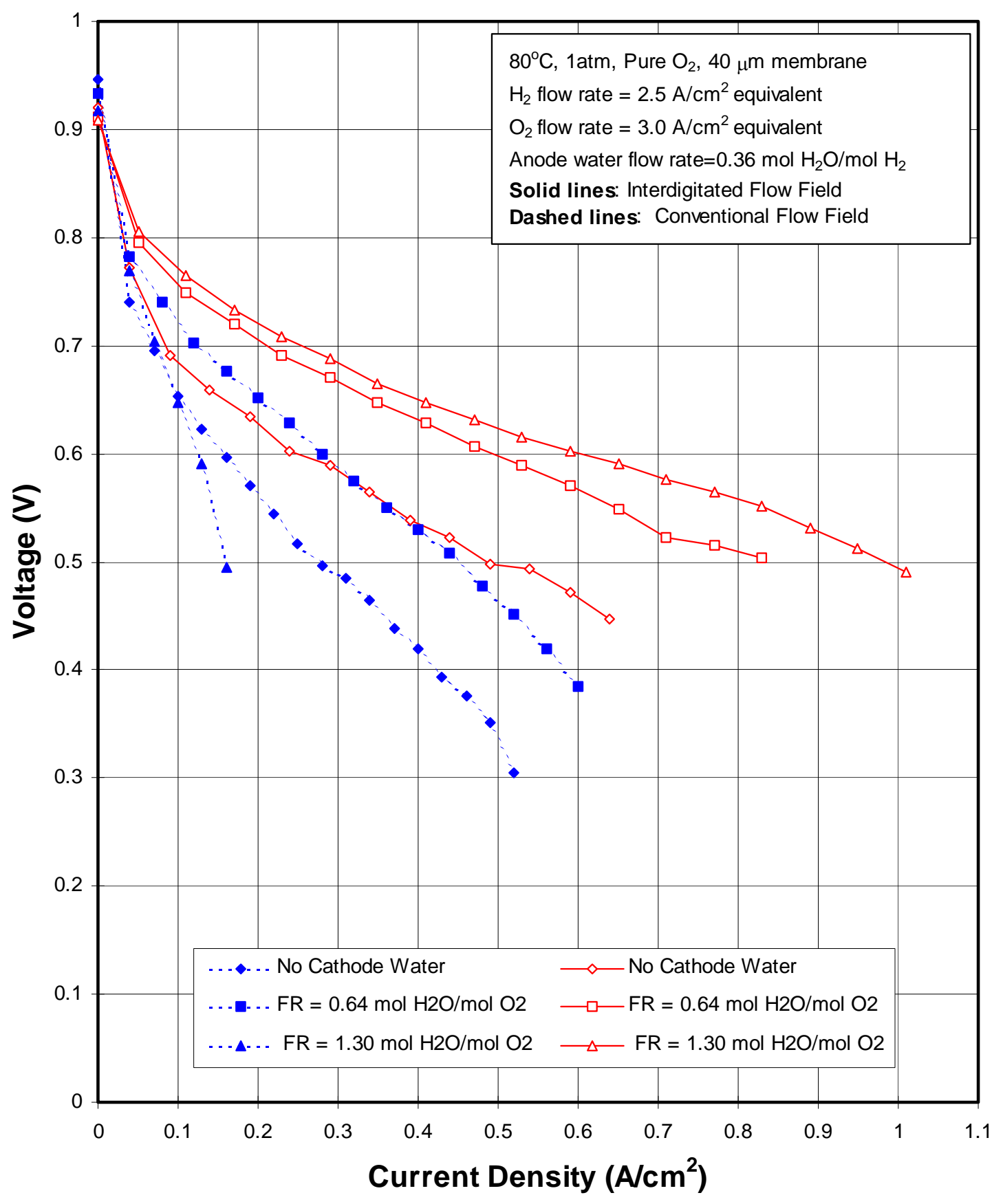

Figure 7. Performance comparison at $80^{\circ} \mathrm{C}$ between flow field designs using $\mathrm{O}_{2} / \mathrm{H}_{2}$ at various cathode water injection levels. 


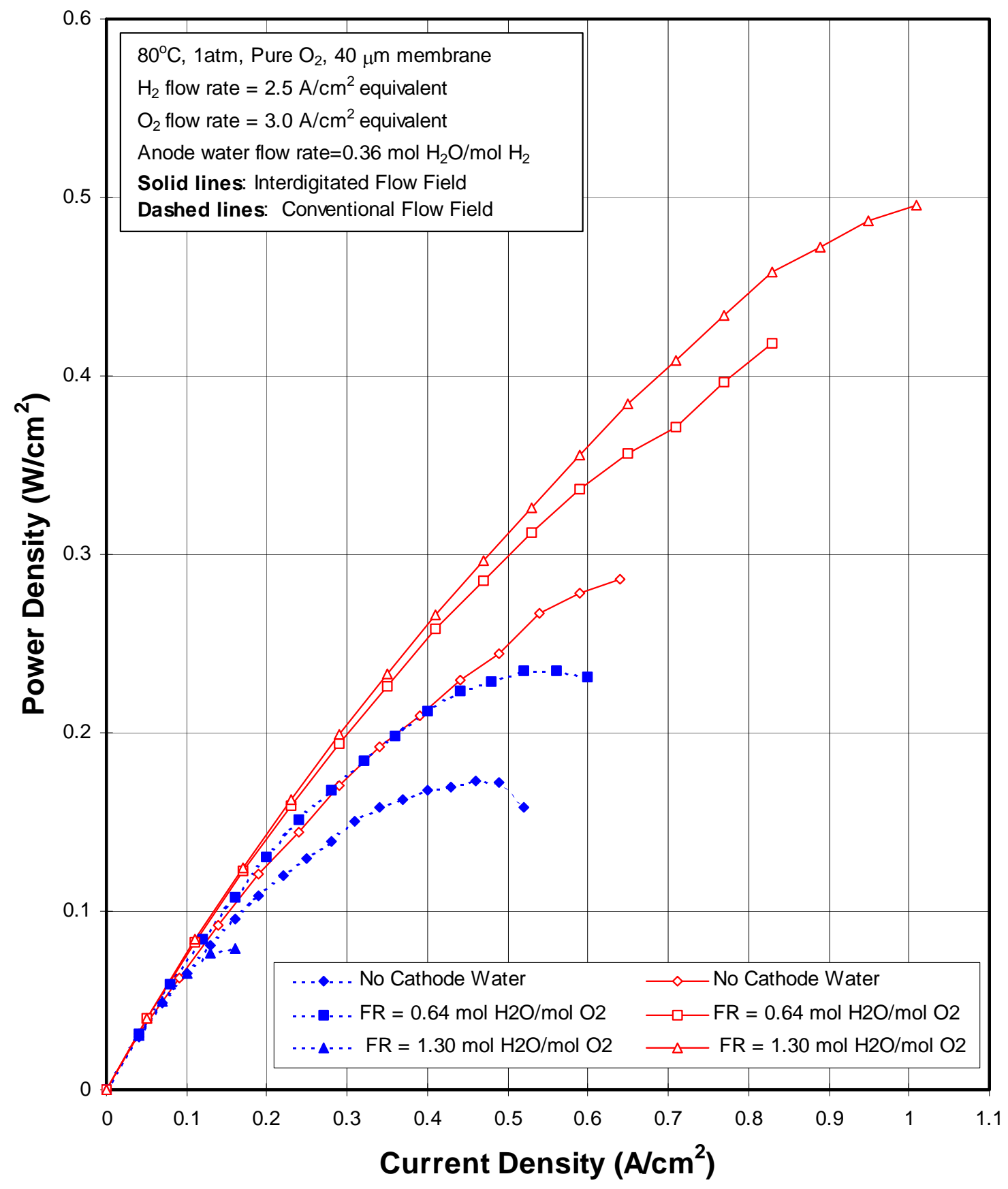

Figure 8. Power density comparison at $80^{\circ} \mathrm{C}$ between flow field designs using $\mathrm{O}_{2} / \mathrm{H}_{2}$ at various cathode water injection levels. 


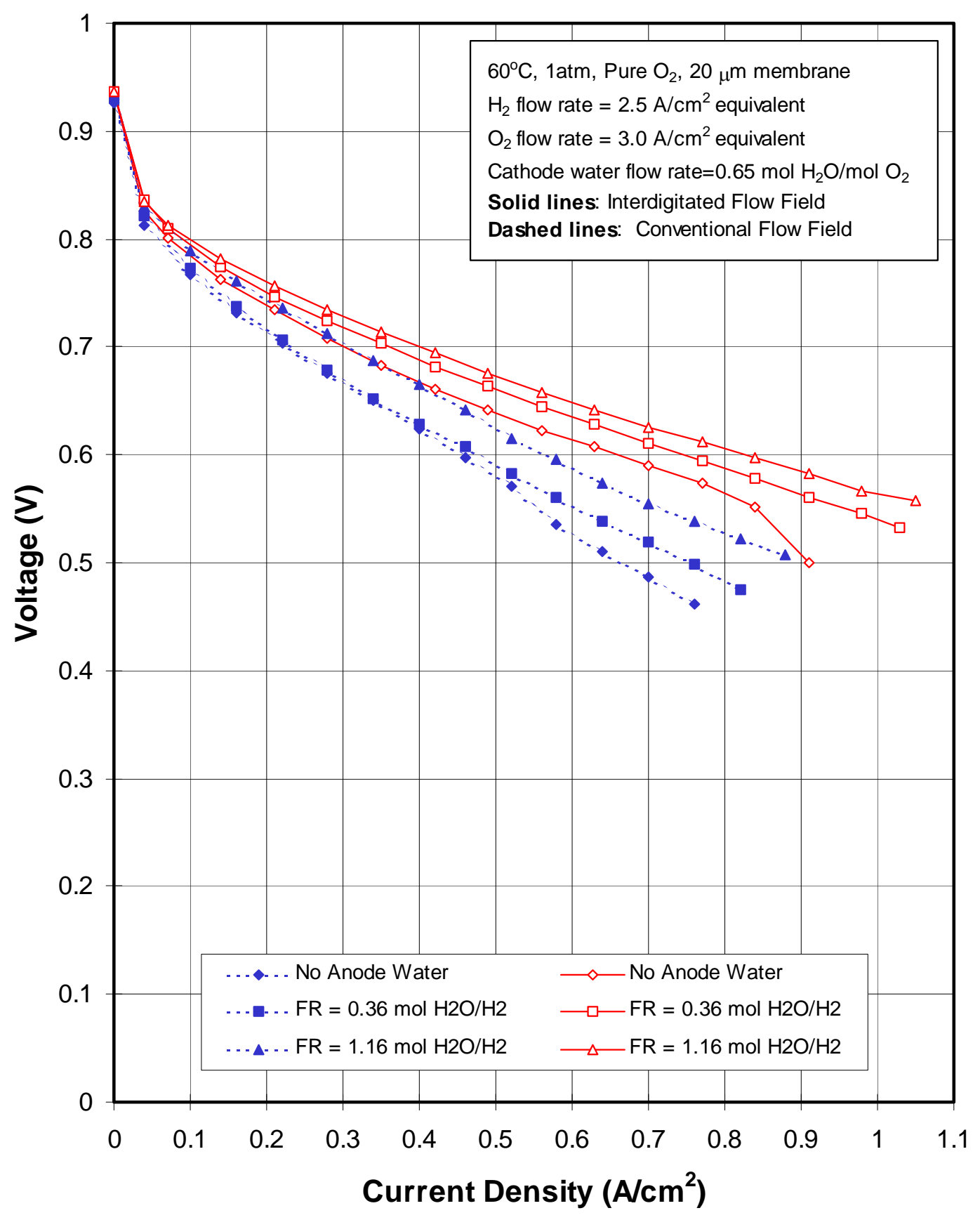

Figure 9. Performance comparison at $60^{\circ} \mathrm{C}$ between flow field designs using $\mathrm{O}_{2} / \mathrm{H}_{2}$ at various anode water injection levels for a thinner $(20 \mu \mathrm{m})$ membrane. 


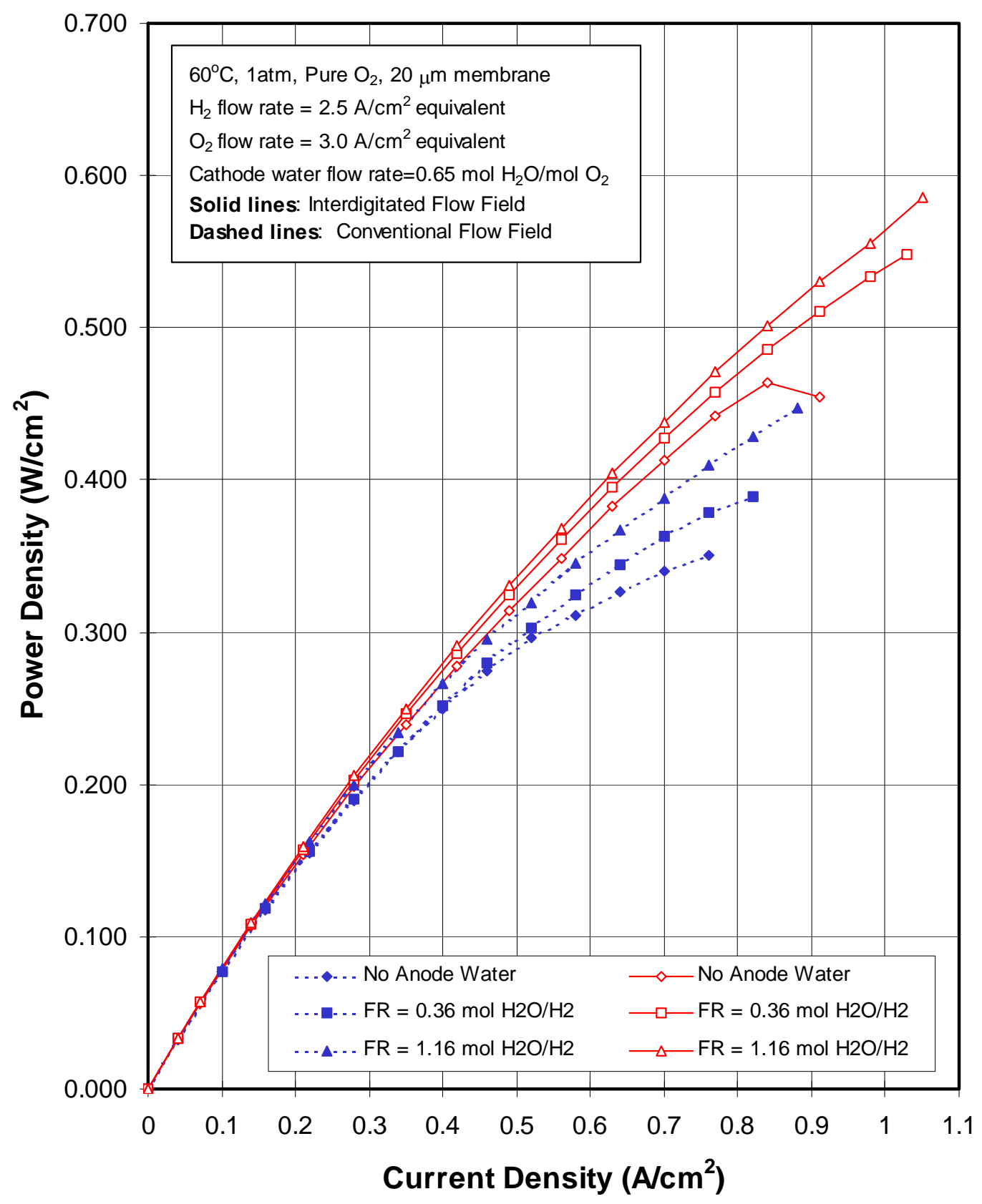

Figure 10. Power density comparison at $60^{\circ} \mathrm{C}$ between flow field designs using $\mathrm{O}_{2} / \mathrm{H}_{2}$ at various anode water injection levels for a thinner $(20 \mu \mathrm{m})$ membrane. 


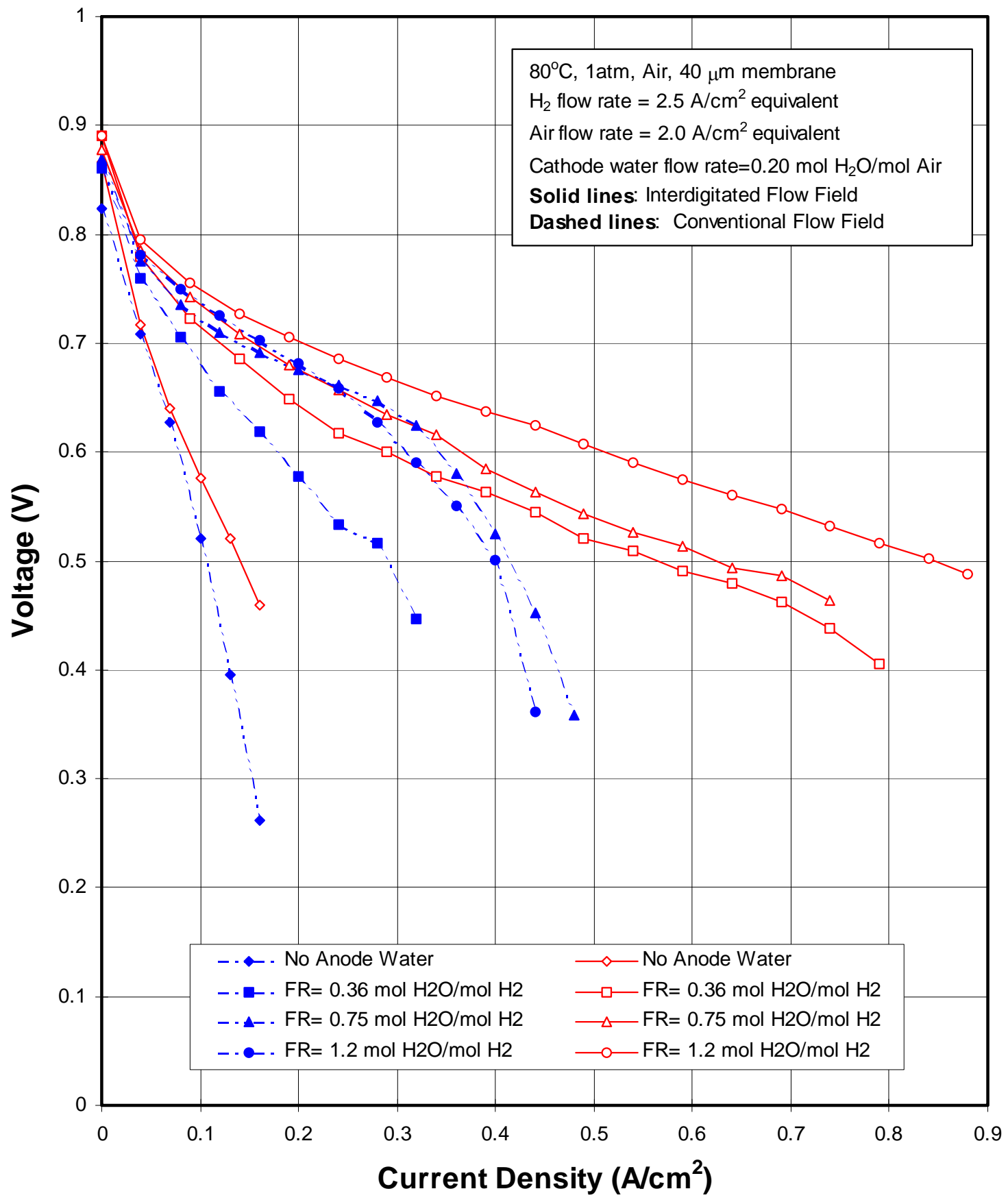

Figure 11. Performance comparison at $80^{\circ} \mathrm{C}$ between flow field designs using Air/ $\mathrm{H}_{2}$ at various anode water injection levels. 


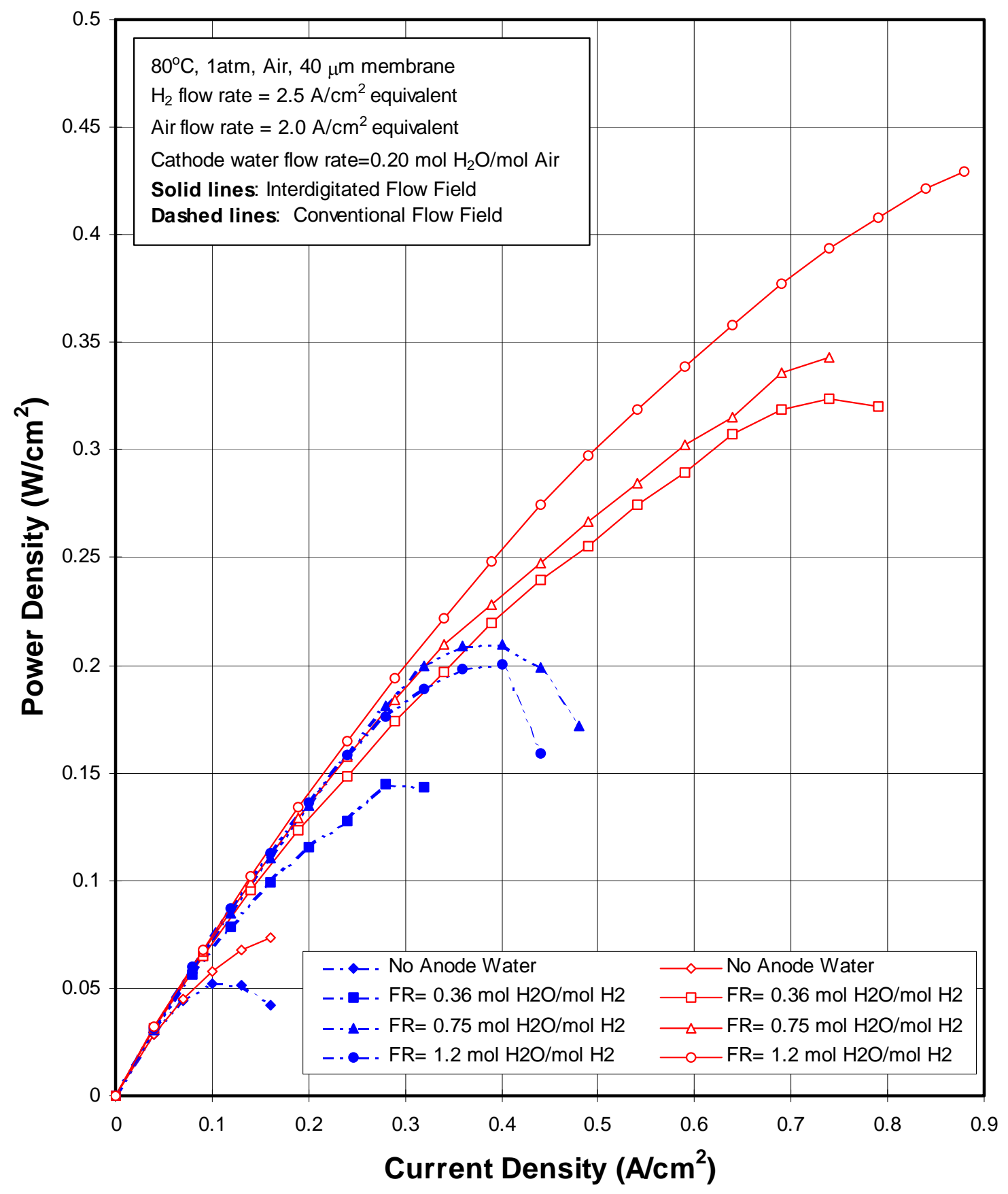

Figure 12. Power density comparison at $80^{\circ} \mathrm{C}$ between flow field designs using Air/ $\mathrm{H}_{2}$ at various anode water injection levels. 


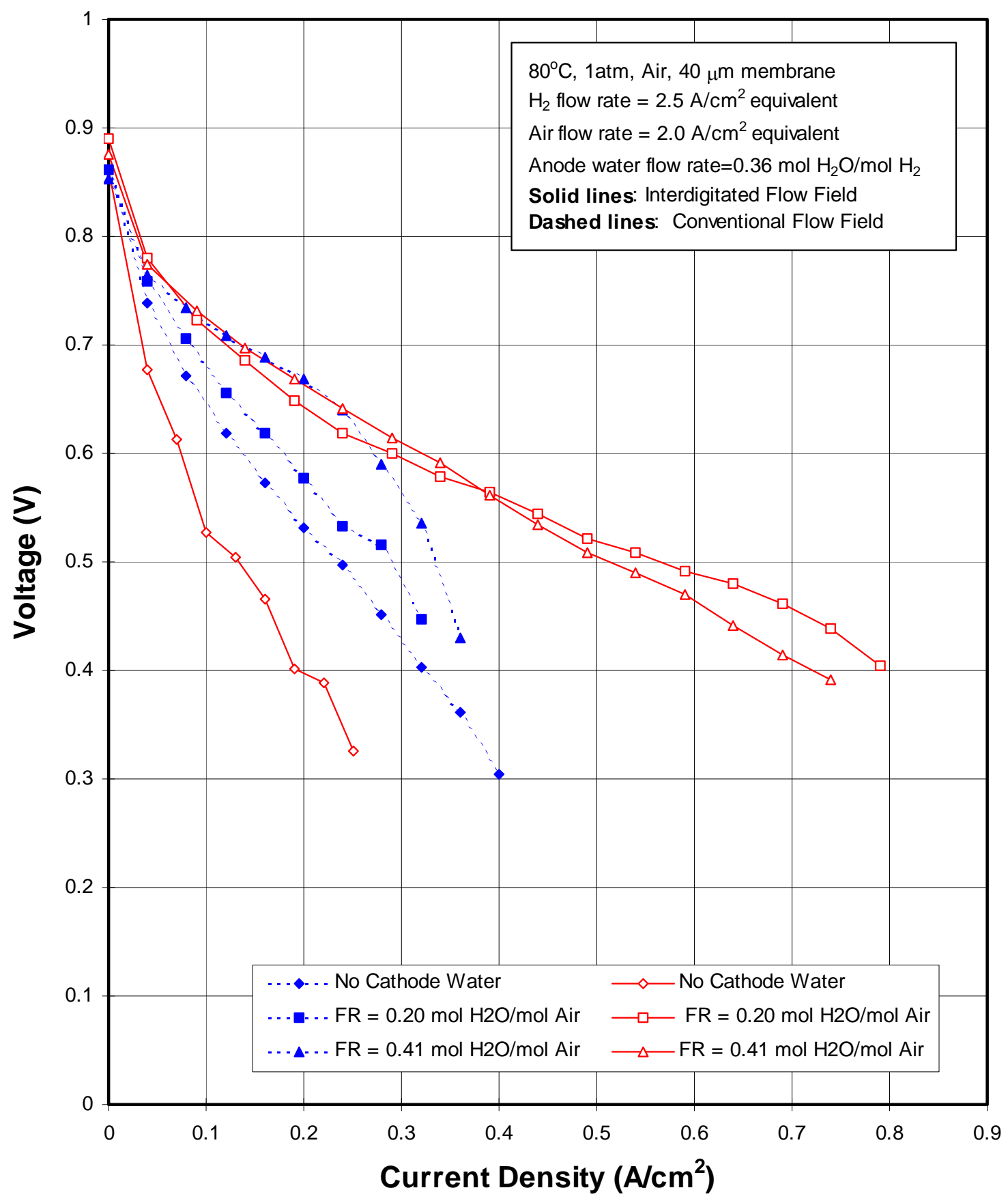

Figure 13. Performance comparison at $80^{\circ} \mathrm{C}$ between flow field designs using $\mathrm{Air} / \mathrm{H}_{2}$ at various cathode water injection levels. 


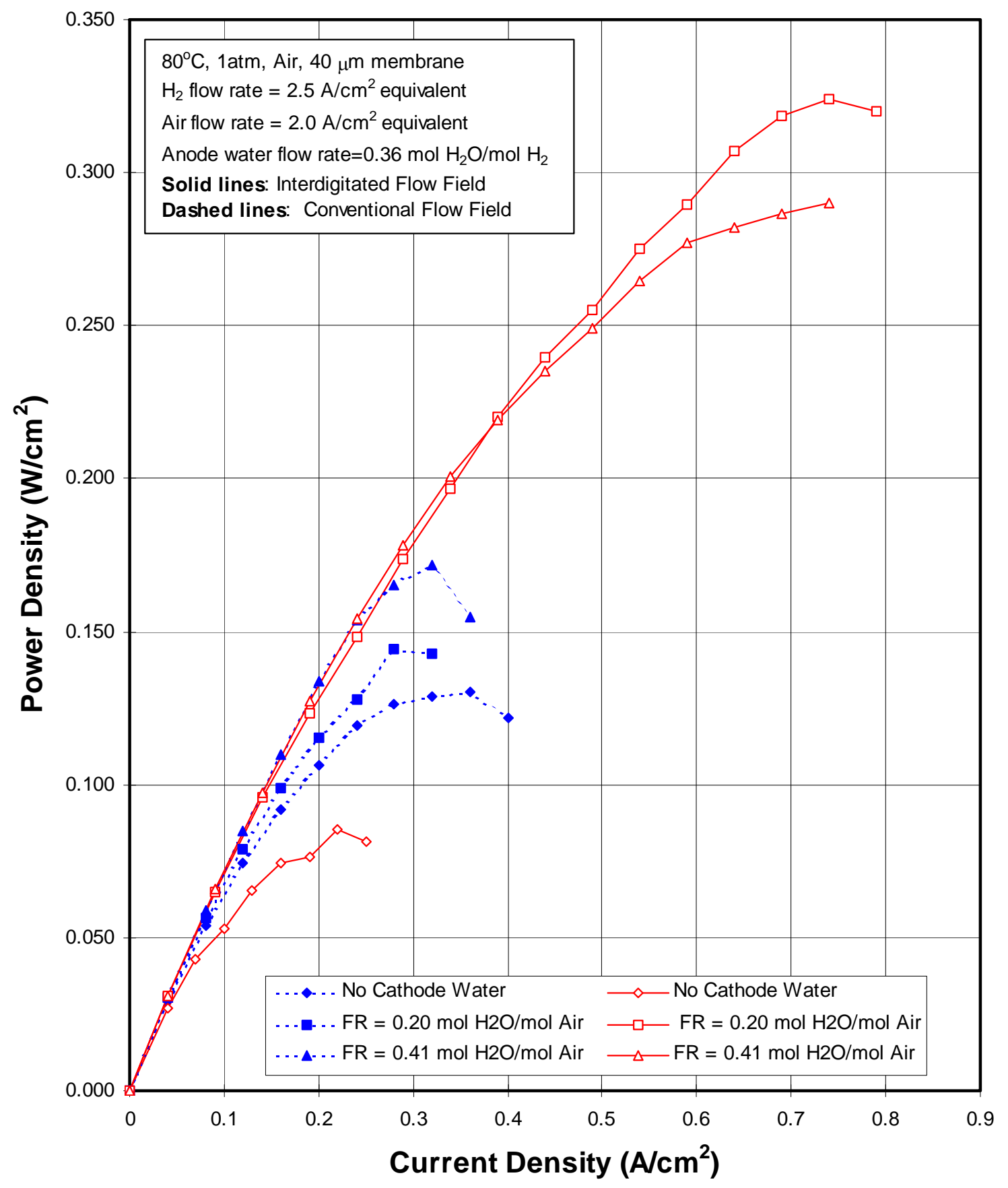

Figure 14. Power density comparison at $80^{\circ} \mathrm{C}$ between flow field designs using Air/ $\mathrm{H}_{2}$ at various cathode water injection levels. 